\title{
STRATEGIC IMPERATIVES ENSURING POPULATION WELFARE UNDER TRANSFORMATION EXCLUSION CONDITIONS
}

\author{
Viktoriia Druzhynina' ${ }^{1}$ \\ Kremenchuk Mykhailo Ostrohradskyi National University, Ukraine \\ Ganna Likhonosova² \\ Volodymyr Dahl East Ukrainian National University, Ukraine
}

\begin{abstract}
The purpose of the research is to substantiate strategic imperatives that should be taken into account in developing algorithms for improving the welfare of the population in the conditions of socio-economic transformation and the emergence of exclusion impulses. The subject of the research is the theoretical and applied aspects of the development of strategic imperatives for the transformation of socio-economic relations in different regions of Ukraine. The methodology of the research is based on methods of correlation-regression analysis - to assess the standard of living of the population, taking into account regional specifics; logical-heuristic, economic-mathematical analysis - to identify the relationship between the needs of the population of different regions and their priority; spatial vector modelling - to predict the level of average wages of the population; as well as for diagnosing the welfare of the population, taking into account the influence of factors of socio-economic transformation and emerging rejection; inverse method - the adequacy of the obtained models and forecasts with the help of verification of predictive values is checked. Results. The research confirmed that the effectiveness of achieving the welfare of the population depends on the degree of restrictions within the framework of socio-economic transformations, the emergence of impulses of social and economic exclusion. The authors developed an algorithm for estimating and modelling the living standards of the urban population. The implementation of the algorithm occurs by: determining the result indicator of the living standards of the population of the city to select the priority factors of influence on the result indicator; detection of the dependence between the result indicator and the factors of influence; the choice of the optimal predictive function for the forecast of the development of the main components (factors) of the result indicator; forecast of the level of the result indicator. At the stages of implementation of the algorithm, a multivariate econometric model for forecasting the living standards of the urban population is constructed. The model proposed by the author is adequate, its statistical quality, significance, and reliability are sufficient for use in forecasting socio-economic processes of city development. The practical significance of the study is to provide methodological and applied tools for finding compromise solutions to neutralize the negative effects of socioeconomic rejection and to promote the welfare of the population in different regions of Ukraine, which unites the entire Ukrainian nation to address the priority tasks that provide the maximum socio-economic effect. Value/originality. The conducted research allowed confirming the obtained results: the implementation of a phased algorithm for forecasting the standard of living of the population depends on a set of strategic and alternative transformational decisions; prolongation of studies of processes of socioeconomic transformation and emerging rejection is ensured by the influence of factors of increasing or decreasing welfare of the population; the level of wages, as an indicator of the quality of life of the population, contributes to the formation of a strategy for improving the welfare of the population. Such a complex of actions aimed at solving the problems of finding alternative solutions, adopting, implementing and monitoring the concerted actions of the population and governmental organizations will strategically ensure the achievement of high quality and standard of living of people, giving them the opportunity to realize their own development goals.
\end{abstract}

Key words: strategic imperatives, welfare, population, socio-economic transformation, exclusion impulses.

JEL Classification: A13, C02, R11

\footnotetext{
Corresponding author:

${ }^{1}$ Department of Tourism, Kremenchuk Mykhailo Ostrohradskyi National University.

E-mail: drughinina.vd@gmail.com

orcid.org/0000-0001-8776-1408

${ }^{2}$ Department of Taxation and Social Economics, Volodymyr Dahl East Ukrainian National University.

E-mail: a.likhonosova@gmail.com

orcid.org/0000-0001-6552-8920
} 


\section{Introduction}

The main purpose of the activity of state and local authorities is to increase the welfare of the population both at the state, regional, and local levels. In order to accelerate the integration processes in the European economic and social space, it is necessary to ensure sustainable social and economic development of the population throughout the territory of Ukraine. Qualitative diagnostics of the welfare of the population, taking into account a large number of socio-economic factors affecting it, is an important tool in the development and implementation of state social policy. The peculiarity of socio-economic development of the population of Ukraine to date is the presence of highly polarized types of levels and quality of life, which requires the use of various evaluation techniques and forecasting (Belyaeva, 2009).

\section{Results of previous researches}

Scientific developments of many foreign and domestic authors are devoted to issues of estimating the welfare of the population using the system of indicators. Among the scholars who suggested ways to measure welfare and poverty, examined the relationship between the dynamics of indicators that characterize them and the economic growth at the national and regional levels, one should distinguish the work of scientists from the Institute of Demography and Social Studies E. Libanova (Libanova, 2007), O. Makarova (Makarova \& Hladun, 2012), V. Pryimak (Pryimak, 2011), A. Ihnatiuk (Ihnatiuk, 2010), V. Druzhynina (Druzhynina \& Zalunina, 2017), and others.

Theoretical and methodological aspects of living standards of the population are investigated in the works of A.G. Smith (Smith, 1997), A.C. Pigou (Pigou, 1932), A. Sen (Sen, 1987), V. Mandybura (Mandybura, 1998), V. Zherebin and A. Romanov (Zherebin \& Romanov, 2015), I. Kholodok (Kholodok. \& Lysenko, 2011). The problems of assessing the standard of living of the population were revealed in writings by the following researchers: T. Popova (Popova, 2011), O. Omelchenko (Omelchenko, 2010), V. Druzhynina (Druzhynina \& Chornous, 2011), H. Likhonosova (Likhonosova, 2012). A significant contribution to the research of practical aspects of the application of statistical methods and models of diagnosis of living standards and social modelling was made by K. de Green (Green, 1987), H. Verbytska (Verbytska, 2010).

However, despite a number of scientific works, the question of a qualitative assessment of the welfare of the population at the local level, due to a large number of factors influencing it, remains rather controversial. That is why the question of estimating and forecasting the welfare of the urban population is raised by the prism of its basic indicator of living standards. After all, raising the living standards of the population at the local level will contribute to the improvement of the socio-economic situation of the population at all administrative-territorial levels.

\section{Empirical studies of the impact of socio-economic transformations on the welfare of the population}

The priority direction of development for Ukraine and its territorial-administrative units, in particular, is raising the level of welfare of the population. The system of modern state administration in the country is rather imperfect and ineffective, which leads to a decrease in the welfare of Ukrainians in general and its material component - the standard of living - in particular. In this regard, a large number of scientists and researchers investigate current problems of the present, namely, the standard of living of the population.

The standard of living of the population is a socioeconomic category that helps describe the material welfare not only of the individual but also defines the general result of economic development in the country over a certain period of time. This is quite a dynamic category, which depends on the specific conditions of development of the country and society, therefore, according to the objectives of the research, its content is also determined, which greatly influenced on the differences in methods of evaluation. Hence, it can be concluded that the standard of living is quite complex and multifaceted concept, which combines in itself a number of socio-economic relations, which are connected with the state and the conditions of life of people in society (Verbytska, 2010). It should be noted that the effectiveness of social policies of local authorities determined the living standards of its people because their main aim is to ensure economic growth and social stability on the local level, improving the material welfare and protection of its vulnerable strata, the material and spiritual needs of people, etc. The spatial research base is city Kremenchuk, assessment of living standards, which should begin by multivariate modelling in system integrated assessment through the algorithm, which consists of certain phases (Fig. 1).

On the first phase of the study, it is advisable to choose the resulting index for assessing the level of life of the city population. The average wage in the city Kremenchuk was such the resulting index $(\mathrm{Y})$.

On the second stage of the study, it is necessary to choose the key indicators of socio-economic development (factor values) for assessing the impact of the factors; it is listed in Table 1 (The Main Statistical Office in Poltava region).

To assess the standard of living, on the third stage, there was chosen a method of correlation and regression analysis through a number of advantages of it: firstly it is available for PC users; secondly it helps to identify and 


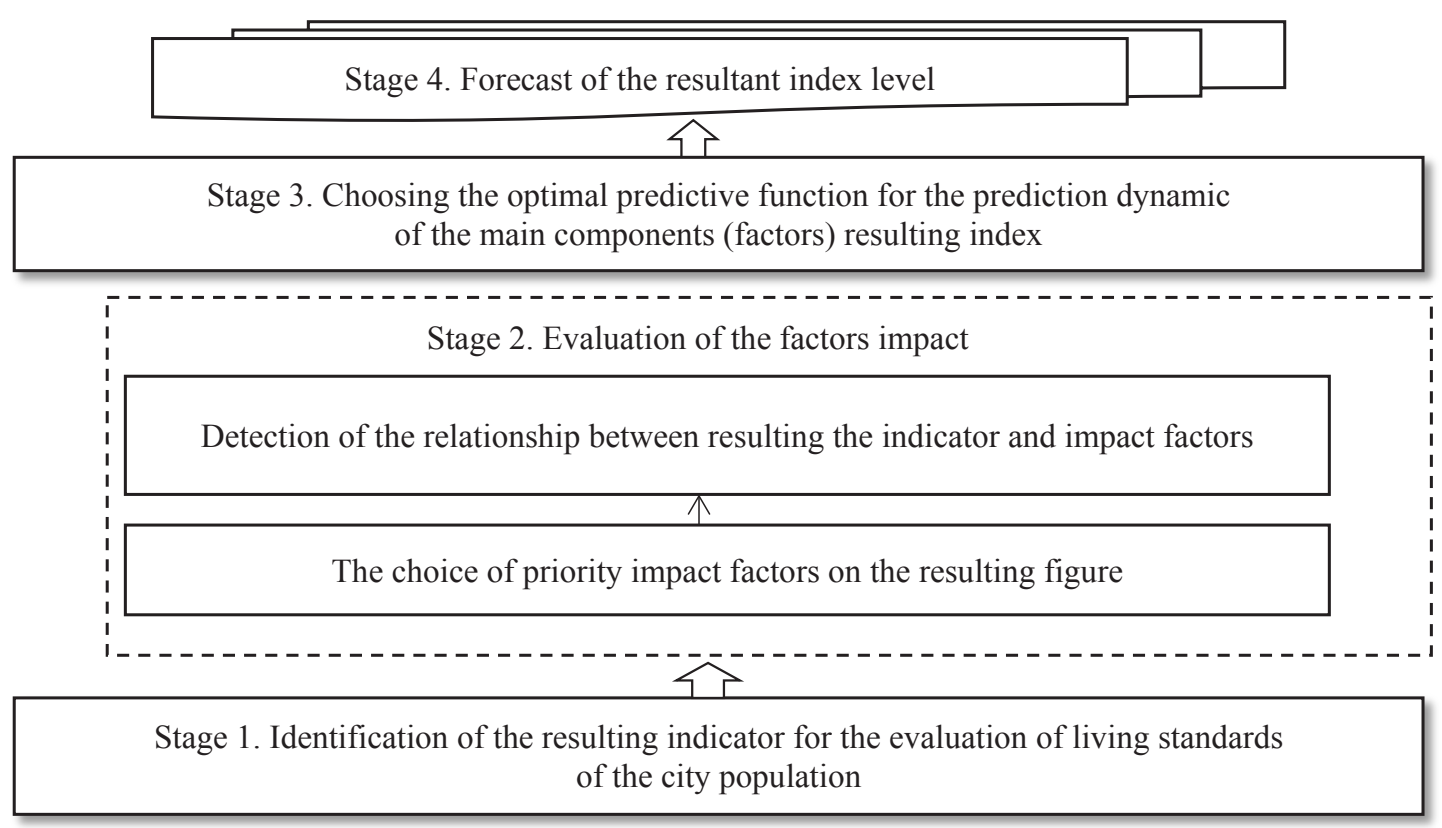

Fig. 1. Stages of forecasting of urban population life level

Source: compiled by the authors

Table 1

Summary indicators for the assessment of living standards of the population in Kremenchuk

\begin{tabular}{|l|c|c|c|c|c|c|c|c|}
\hline \multirow{2}{*}{ Name of indicator } & \multicolumn{7}{|c|}{ Value index by years } \\
\cline { 2 - 9 } & 2008 & 2009 & 2010 & 2011 & 2012 & 2013 & 2014 & 2015 \\
\hline Average salary, UAH $(\mathrm{Y})$ & 2079 & 1960 & 2445 & 3036 & 3321 & 3522 & 3398 & 4043 \\
\hline Gross value added, million UAH $\left(\mathrm{X}_{1}\right)$ & 15603,6 & 10142,4 & 10345,2 & 14190,3 & 1527,5 & 13350,8 & 4957,4 & 4902,3 \\
\hline $\begin{array}{l}\text { The number of small businesses per } 10 \\
\text { thousand people, units }\left(\mathrm{X}_{2}\right)\end{array}$ & 73 & 73 & 74 & 75 & 78 & 138 & 152 & 149 \\
\hline $\begin{array}{l}\text { The size of the subsistence minimum per } \\
\text { person per month, UAH }\left(\mathrm{X}_{3}\right)\end{array}$ & 601 & 664 & 849 & 923 & 1050,6 & 1147 & 1218 & 1330 \\
\hline $\begin{array}{l}\text { The number of industrial personnel, } \\
\text { persons }\left(\mathrm{X}_{4}\right)\end{array}$ & 2270 & 2188 & 2057 & 2082 & 2219 & 2128 & 1582 & 1386 \\
\hline Productivity, thousand UAH $\left(\mathrm{X}_{5}\right)$ & 249,47 & 181,36 & 191,28 & 198,3 & 217,63 & 160,32 & 119,19 & 101 \\
\hline The migration balance, people $\left(\mathrm{X}_{6}\right)$ & 536 & 75 & 392 & 389 & 249 & 669 & 223 & -441 \\
\hline Nominal wages, UAH $\left(\mathrm{X}_{7}\right)$ & 2080 & 1960 & 2609 & 3036 & 3386 & 3350 & 3398 & 4044 \\
\hline The inflation index, \% $\left(\mathrm{X}_{8}\right)$ & 122,3 & 112,3 & 109,1 & 104,6 & 99,8 & 100,5 & 124,9 & 143,3 \\
\hline Minimum wage in Ukraine, UAH $\left(\mathrm{X}_{9}\right)$ & 605 & 744 & 922 & 1004 & 1134 & 1147 & 1301 & 1378 \\
\hline Arrears of wages, UAH $\left(\mathrm{X}_{10}\right)$ & 7707,2 & 6870,4 & 2452,7 & 997,7 & 1253 & 1240,9 & 2161,8 & 3681,5 \\
\hline
\end{tabular}

Source: Compiled by the authors using data from http://pl.ukrstat.gov.ua

quantify measure the level of influence of individual factors on the object of research; thirdly, on the basis of actual data of model, it is possible to realize forwardlooking assessment of the investigated object (Pidhornyi \& Vitkovska, 2012).

To detect the relationship between the resulting index and the factors that influence it using linear equations multivariable regression type:

$$
\mathrm{Y}=\alpha_{0}+\alpha_{1} \mathrm{x}_{1}+\alpha_{2} \mathrm{x}_{2}+\cdots+\alpha_{\mathrm{n}} \mathrm{x}_{\mathrm{n}} \text {, }
$$

where $\mathrm{Y}$ - the resulting figure; $\mathrm{x}_{1}, \mathrm{x}_{2}, \ldots, \mathrm{x}_{\mathrm{n}}$ - factors of influence; $\alpha_{0}, \alpha_{1}, \ldots, \alpha_{\mathrm{n}}$ - parameters of the model, which need to be estimated (regression coefficients).
To identify the link between the resulting index (average salary) and the factors that influence it, it is necessary to build matrix coefficients of correlation of factors that influence the resulting index (Table 2).

In the process of analysing the data of Table 2, under the conditions of eliminating multicollinearity, as factors of impacts on the resulting figure are elected as follows: the number of small enterprises $\left(\mathrm{X}_{2}\right)$; cost of minimum living standards $\left(\mathrm{X}_{3}\right)$; productivity $\left(\mathrm{X}_{5}\right)$; nominal wages $\left(\mathrm{X}_{7}\right)$; minimum wage $\left(\mathrm{X}_{9}\right)$.

Generated results of regression analysis between average wages and selected indicators that affect it are given in Tables $3-5$. 
Table 2

Matrix interconnection of paired correlation coefficients of factors that impact on resulting index

\begin{tabular}{|c|c|c|c|c|c|c|c|c|c|c|c|}
\hline & $\mathrm{X}_{1}$ & $\mathrm{X}_{2}$ & $\mathrm{X}_{3}$ & $\mathrm{X}_{4}$ & $\mathrm{X}_{5}$ & $\mathrm{X}_{6}$ & $\mathrm{X}_{7}$ & $\mathrm{X}_{8}$ & $\mathrm{X}_{9}$ & $\mathrm{X}_{10}$ & $\mathrm{Y}$ \\
\hline $\mathrm{X}_{1}$ & 1 & & & & & & & & & & \\
\hline $\mathrm{X}_{2}$ & $-0,346$ & 1 & & & & & & & & & \\
\hline $\mathrm{X}_{3}$ & $-0,595$ & 0,851 & 1 & & & & & & & & \\
\hline $\mathrm{X}_{4}$ & 0,492 & $-0,798$ & $-0,766$ & 1 & & & & & & & \\
\hline $\mathrm{X}_{5}$ & 0,446 & $-0,873$ & $-0,803$ & 0,901 & 1 & & & & & & \\
\hline $\mathrm{X}_{6}$ & 0,609 & $-0,334$ & $-0,416$ & 0,721 & 0,616 & 1 & & & & & \\
\hline $\mathrm{X}_{7}$ & $-0,581$ & 0,741 & 0,972 & $-0,703$ & $-0,682$ & $-0,421$ & 1 & & & & \\
\hline $\mathrm{X}_{8}$ & $-0,229$ & 0,510 & 0,303 & $-0,787$ & $-0,564$ & $-0,726$ & 0,275 & 1 & & & \\
\hline $\mathrm{X}_{9}$ & $-0,657$ & 0,806 & 0,991 & $-0,774$ & $-0,808$ & $-0,459$ & 0,961 & 0,284 & 1 & & \\
\hline $\mathrm{X}_{10}$ & 0,317 & $-0,306$ & $-0,666$ & 0,194 & 0,290 & $-0,144$ & $-0,691$ & 0,411 & $-0,692$ & 1 & \\
\hline $\mathrm{Y}$ & $-0,522$ & 0,780 & 0,972 & $-0,681$ & $-0,689$ & $-0,378$ & 0,993 & 0,258 & 0,952 & $-0,674$ & 1 \\
\hline
\end{tabular}

Source: the authors' calculations based on statistics (The Main Statistical Office in Poltava region)

Table 3

\section{Regression statistics}

\begin{tabular}{|l|l|}
\hline Multiple regression coefficient $\mathrm{R}$ & 0,996360245 \\
\hline The coefficient of determination $\mathrm{R}^{2}$ & 0,992733738 \\
\hline Normalized coefficient of determination $\mathrm{R}^{2}$ & 0,974568082 \\
\hline Standard error & 118,3632328 \\
\hline
\end{tabular}

Source: the authors' calculations based on statistics (The Main Statistical Office in Poltava region)

Multiple regression coefficient $\mathrm{R}=0,996$ indicates a very tight relationship between the resulting indicator and factor values. The concern of the value of the coefficient of determination $\mathrm{R}^{2}$ in obtained correlationregression model $R^{2}=0,993$, so, the dependence of the average wage to $99.3 \%$ due to selected factor values.

This dependence is quite legitimate with considering high coefficients of multiple regression and determination. An indicator of significance $\mathrm{F}$ indicates that the evaluation results are sufficiently reliable. It makes sense to look at variance and F-statistics, so their higher value indicates a variation of the dependent and independent variable, so the regression equation is significant.

Thus, the regression equation, which is based on Table 5, would look like this:

$$
\begin{aligned}
& Y=-125,85+1,133 X_{2}+1,553 X_{3}+0,429 X_{5}+ \\
& +0,911 X_{7}-1,282 X_{9} .
\end{aligned}
$$

Through analyzing the regression equation may be made the following conclusions: as the number of small businesses per 10 thousand of present population grow on one unit, the average wage in Kremenchuk increase by $1,13 \mathrm{UAH}$; by increasing the subsistence minimum on $1 \mathrm{UAH}$, the average salary will increase by
Table 5

Estimates coefficients

of the five-factors regression model

\begin{tabular}{|c|c|c|c|c|}
\hline Indicators & Coefficients & $\begin{array}{c}\text { Standard } \\
\text { error }\end{array}$ & $\begin{array}{c}\mathrm{t} \text { - criteria of } \\
\text { Student }\end{array}$ & P-value \\
\hline Y & $-125,855$ & 904,328 & $-0,139$ & 0,902 \\
\hline X2 & 1,133 & 6,230 & 0,182 & 0,872 \\
\hline X3 & 1,553 & 3,921 & 0,396 & 0,730 \\
\hline X5 & 0,429 & 2,686 & 0,160 & 0,888 \\
\hline X7 & 0,911 & 0,497 & 1,834 & 0,208 \\
\hline X9 & $-1,282$ & 2,467 & $-0,520$ & 0,655 \\
\hline
\end{tabular}

Source: the authors' calculations based on statistics (The Main Statistical Office in Poltava region)

1,55 UAH; while increasing productivity for $1 \mathrm{UAH}$ the average salary increase almost by $0,43 \mathrm{UAH}$; by increase in nominal wages on $1 \mathrm{UAH}$, the average salary will increase by $0,91 \mathrm{UAH}$; by increasing the minimum wage on $1 \mathrm{UAH}$, the average wages reduced on 1,28 UAH.

Thus, the data of made correlation-regression analysis indicate that the selected factors have a significant impact on the average wage in the city Kremenchug and it requires more careful analysis. At the local level for improving the living standards, it is necessary to ensure the stable development of the small and middle business. Increasing the number of small businesses will provide more job places and will contribute to increased productivity in enterprises of the city. However, despite the increase in productivity, raising the minimum wage would reduce the average wage. This is because in times of crisis, companies do not fully use their potential as productive and skilled, what is displayed on the average wage. The minimum wage, in turn, should be reviewed depending on changes in the subsistence minimum

Table 4

Indicators, which describe the reliability of regression model

\begin{tabular}{|c|c|c|c|c|c|}
\hline & Df & SS & MS & F & Significance F \\
\hline Regression & 5 & 3828118,29 & 765623,6581 & 54,64893569 & 0,018066778 \\
\hline Remainder & 2 & 28019,70975 & 14009,85487 & & \\
\hline Total & 7 & 3856138 & & & \\
\hline
\end{tabular}

Source: the authors' calculations based on statistics (The Main Statistical Office in Poltava region) 
value of which is the social standard of the state. This index serves both such a factor influence on living standards of the population and an indicator of living in the country. Therefore, increasing the living wage at the national level will contribute to social security and growth of standards of social and medical services for the population.

In order to provide the effectiveness of developed regional and local socio-economic strategies of development, it is necessary to predict the level of life of the urban population. On the third stage, the forecast of the average wage was done by using the least squares method, which is used for predicting socio-economic processes (Druzhynina, 2014). To confirm the accuracy of the constructed econometric model and obtain predictive values, there was carried out a verification of predicted values by invert method and by graphs of dynamics of actual and estimated levels of the average wage (Fig. 2).

Through the results of the verification made, calculation error does not exceed 5\%, confirming the adequacy of the model and derived predictions.

In order to obtain accurate and reliable data forecast, a period from 2016 to 2019 was chosen, as making a forecast for a longer period is not appropriate taking into account the instability of the economic, social, and political situation in Ukraine. By using the method of least squares obtained the following results of forecast factor indicators: the number of small businesses from 2016 to 2019 increased by $24.8 \%$; the subsistence minimum per person per month $21.9 \%$; productivity will decrease in 2019 to $50.3 \%$ compared to the year 2016; nominal and minimum wage from 2016-2019 will increase by $19,8 \%$ and $21,3 \%$ respectively.

On the fourth stage, there are made forecasts on the average wage in Kremenchuk, which are based on forecast data and regression equation (Fig. 3).

Despite the crisis phenomenon in the economy of the country, this forecast suggests a gradual increase of the average wage in Kremenchuk, for forecast period it is nearly $20.3 \%$, due to an increase in the number of small businesses; increase in subsistence level; growth of productivity and nominal and minimum wages. Thus, the standard of living in Kremenchuk tends to improve.

So, as a result of the research, the following conclusions can be reached: firstly, developed and implemented step-by-step algorithm for the prediction of urban population level of life; secondly, by using correlation

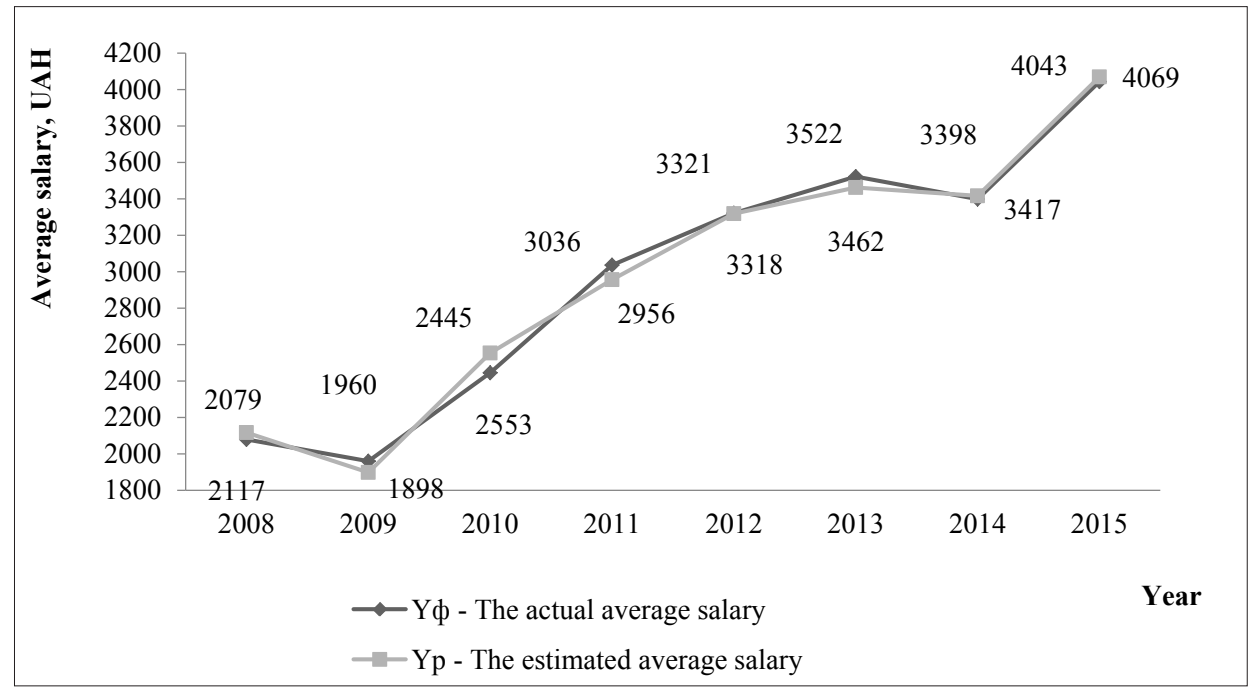

Fig. 2. Trend changes of actual and estimated levels of the average wage in Kremenchuk

Source: built by the authors' calculations

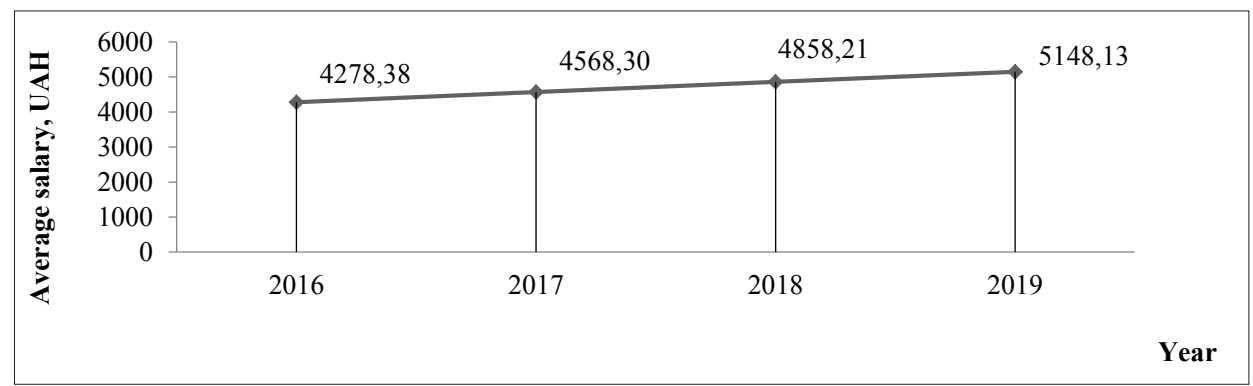

Fig. 3. Forecasting the level of the average wage in Kremenchuk

Source: built by the authors' calculations 
and regression analysis, there are found factors that influence the city development, which will allow for the extending studies of socio-economic processes; thirdly, foundation of the average wage as an indicator for measuring living standards will promote a forming strategy for the socio-economic development city which is aimed at solving issues and finding alternative solutions, adopting, implementing, and monitoring that will be scientific base for the further studies.

\section{Strategic imperatives to increase the welfare of the population at the city level}

In recent years, Kremenchuk has demonstrated a reduction in the economic growth due to the situational adaptation of the pre-crisis model of development. The positive changes in the local labour market of Kremenchuk are developed for 2003-2015. It took place in the environment of controversial tendencies of development of labour markets areas (Hlobynskyi, Dykanskyi, Kotelevskyi) and with consideration of negative trends in the development of local labour markets (PC "Kryukov Railway Car Building Works", JSC "Kremenchuk Steel Works", JSC "Poltava Fan Factory"), which forms the imperatives of structural changes and development of the total of the local labour market.

Taking into account the results of comparing the characteristics of the main components of the balance of labour markets of foreign countries and Ukraine, it is proved that, given the complexity of problems in the labour market in Kremenchuk, we should not focus on ensuring the equilibrium state of the local labour market but on bringing the unbalanced local labour market today to the condition, in which the interests and needs of participants will be taken into account as much as it is possible. It is found that the increase in the imbalance of supply and demand in the local labour market of Kremenchuk is due through, firstly, skill-imbalance of demand and supply of labour, and secondly, increased dual structural imbalance of supply and demand of job places by level of education and in professional qualification segmentation, which makes the need to solve the problem of imbalance on the basis of coordination of industrial, educational, demographic, and migration policy, strategic and tactical approaches to labour market regulation, inter-sectorial cooperation, the integration of efforts of government, business, and educational system.

Based on the assessment of the city's resource potential, trends of socio-economic development in the city of Kremenchuk, changes in the legal framework and certain vectors of the movement, existing problems and possible risks, it is necessary to determine the priorities, objectives, tasks, and measures of the economic and social policy of the city community, which are aimed at increasing the welfare of the population on the basis of taking into account all endogenous and exogenous factors, providing a high-quality and safe environment for the life of the population of Kremenchuk.

In order to increase the welfare of the population, to increase the socio-economic efficiency of the city of Kremenchug, it is necessary to strengthen the coherence of state programs and work of local authorities in improving the economic conditions of the population and its social protection. The main conditions for improving the welfare of the urban population are appropriate approaches.

In forming the strategic imperatives for increasing the welfare of the population of Kremenchuk, the following approaches are used, such as the validity of the methodology for solving the problem: systemic, process, integration, dynamic, optimization, complex, strategic. The number of approaches used depends on the complexity of the system, therefore, the basic approach to solving the problem is a systematic approach, the use of which is due to the complexity of the problem and the need for its study in the unity of legal, economic, social, organizational, managerial, and other aspects; the globalization of competition, production, etc.; strengthening the role of the human factor. Since welfare is seen as a natural system (climate and resource); economic (production, distribution, exchange, consumer, profit, business, property, and financial); institutional (components of security, intellectual, environmental, medical, demographic, psychological, social, educational, cultural, permissive, infrastructure, informational and communicative) components (Druzhynina, 2014), consisting of an internal structure, in which input elements are transformed at weekends in accordance with the stated purpose, and the external environment, the above proves the need for a systematic approach. The economic essence of welfare is determined through its functions, which are in close connection with each other, which necessitates the application of a functional approach.

The achievement of the stated goal of increasing the welfare of the urban population is established as a chain of interconnecting actions, which substantiates the choice of the process approach. When applying a dynamic approach welfare is considered in causal relationships, an analysis of the dynamics of its components in previous years and developed a mediumterm forecast. The integration approach is aimed at studying the relationship between vertical management levels, forming a multi-level system of indicators of population welfare and horizontal, exploring the welfare trends of the population at the same level, for example, at the city level. It is determined that interaction in all directions is carried out, first of all, on the basis of information technologies. The optimization approach is realized by identifying links between the resulting welfare indicators of the population, for example, the standard of living or quality of life, and the economic- 
ecological and social indicators through the methods of analysis, forecasting, and optimization, on the basis of which the imperatives and their directions form the concept of strategic welfare improvement and also the local population, which determines the use of principles of systemic and program-targeted approach.

The program-targeted approach involves the selection of priority goals of economic and social development, the development of interrelated measures for their achievement at the specified time with the maximum efficiency with the necessary resources.

Strategic imperatives should be aimed at mobilizing and concentrating all possible resources for the implementation of tasks of reforming the city economy, developing the economic potential of cities, and achieving European standards of living (Figure 4). The main vectors for improving the welfare of the population at the local level are the following:

- to increase the standard of living of the city's population, strategic costs can be considered as an increase in the labour cost; reducing the proportion of low-income and low-wage workers; poverty reduction; settlement of interqualification relations in wages; elimination of arrears of wages and preventing them in the future; increasing the share of wages in the structure of production costs; observance of state guarantees in wages by all economic entities;

- to improve the quality of life of the population at the local level, it is necessary to ensure the stimulation of competitiveness, innovation processes and productions, the formation of a favourable climate for attracting investments; development of small and medium business; development of transport and road transport infrastructure. The main tasks for the development of transport infrastructure are increasing transport network capacity; introduction of high-speed passenger trains, primarily daily; development of a network of highways, first of all, high-speed and roundabouts of settlements. Transport should ensure the availability and quality of transport services for all segments of the population in accordance with social standards. Taking into account the steady trend towards urbanization and particularly intensive urban development, general purpose transport should become an alternative to individual motor transport. Priorities in the development of public passenger transport are: long-term planning of urban, urban and suburban transport network development through the development of long-term general schemes for urban development, long-term development and transport links; the application of architectural and planning solutions to increase the throughput of the street network; forecasting the demand for passenger urban transportation and its satisfaction with various modes of transport; the optimization of the network of public routes and the structure of the park on the basis of periodic monitoring of passenger traffic; improvement of the city transport management system, including the creation of centres for the regulation of urban traffic; introduction of intelligent traffic control systems in urban areas, modernization of the system of automatic traffic control (traffic lights);

development of traffic safety improvement programs in cities; implementation of projects to reduce the negative impact of urban passenger transport on the environment; providing population with high-quality public passenger transport services in cities, suburban, and rural areas by: developing and implementing state social standards and standards for passenger transport; development of highways; improving the service of people with disabilities; the introduction of a system of mandatory sale of tickets for travel and control over the implementation of such sales; the transfer of functions for the sale of tickets and the collection of revenues during the carriage of passengers in city traffic to customers; development and introduction of a system of cashless payments with the help of SMART-cards for passenger transportation on public bus routes;

- reforming housing and communal services by creating social amenities for the city's territorial community in providing high-quality housing and communal services, repairing the modernization of the housing stock reconstruction, ensuring the reliability of life support systems, comfort and safety of living conditions of the population;

- improving the accessibility, quality, and competitiveness of education through expanding the network of educational institutions for children, taking into account demographic indicators; creation of conditions in educational establishments that meet the modern requirements of educational development and ensure qualitative conducting of educational process; formation of students' skills in the use of information and communication technologies for solving practical problems, research work, self-education, effective communication and cooperation, organization of effective access to them via the Internet;

- implementation of the principle of continuity between pre-primary preparation of primary school pupils and profile education at a senior school; the introduction of inclusive education to support children with special educational needs and the formation of a positive attitude towards people with disabilities in the school environment; ensuring conditions for the development, adaptation in society and preparation for the work of children who need correction of physical and mental development; improvement of areas of work with gifted and talented children and young people, development of effective systems for the identification, training, education, and professional orientation of gifted and talented children and young people; raising the level of scientific and methodological support for pedagogical workers, disseminating advanced pedagogical experience in the city; updating modern computer equipment, technological equipment of 


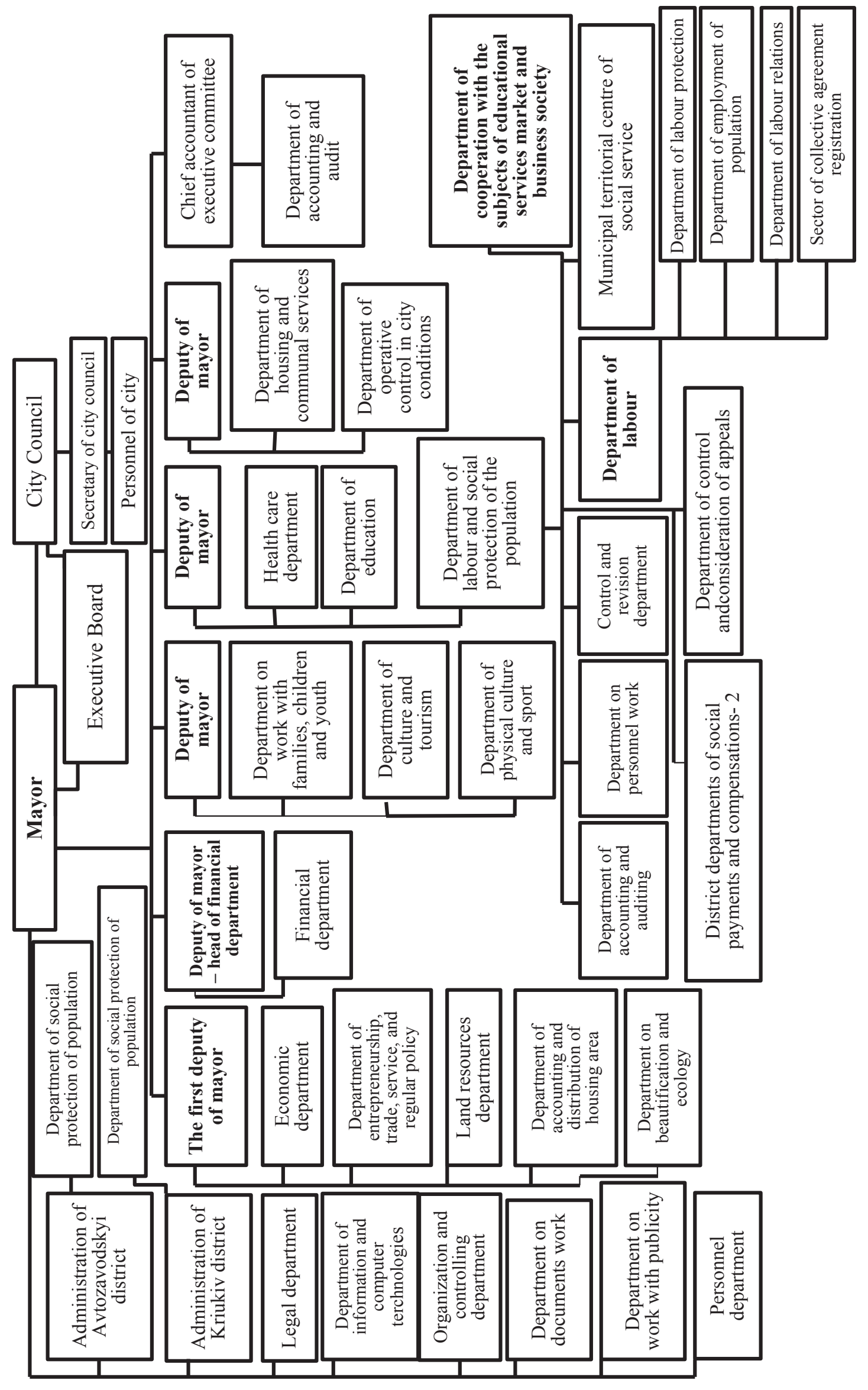

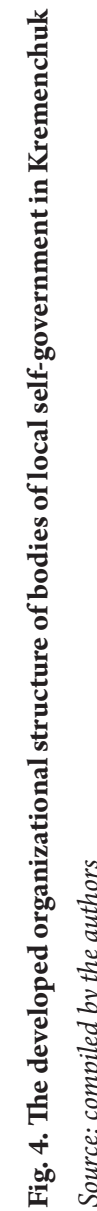


canteens and strengthening material and technical base of educational institutions; provision of full financing of rational and dietary nutrition of schoolchildren; providing for the development of a network of camps for rest with day-care for children on the basis of educational institutions of the city; conducting preventive, health and ecological and valeological educational activities; increasing the autonomy of educational institutions at the disposal of financial resources; stimulating parents' interest in changes in the modern educational space, creating an atmosphere of common interest among teachers and parents;

- reforming the health care system, improving the quality and availability of health care, modernizing primary care, strengthening the material and technical base (equipping/re-equipping) consultative and diagnostic centres through the provision of development of centres for primary medical (health and sanitary) assistance by improving material and technical bases for meeting the needs of the population in primary health care; reorganization of the bad fund of health care institutions providing secondary (specialized) medical care according to the need for its provision to the population; carrying out preparatory work for the organization of hospital districts, which should provide conditions for the provision of secondary (specialized) medical care to the population; redistribution of resources of the city budget between health care institutions providing primary and secondary (specialized) medical care; financing of health care institutions by types of medical care on the basis of contracts on medical care of the population, which are concluded by the main administrators of budget funds of the corresponding level; application of elements of the program-target method of compilation and execution of local budgets in the part of health care expenditures for the corresponding types of medical aid;

- increasing the level of social security of the city's residents, accessibility and quality of social services in the spheres of social protection, culture, physical culture and sports, creating conditions for solving urgent problems of migrants, as well as preserving existing ones and creating new workplaces with proper conditions and decent wages, the growth of the real wage, its transformation into a reliable source of income and timeliness of its payment, which will provide a decent standard of living for the workers and their families;

- ensuring the safety of life and improving the ecological situation in the city through the rational use of the natural resource potential of the city, introduction of eco-safety standards, improvement of the quality of the air basin, preservation of biological and landscape diversity, improvement of the state of green economy (green zone development, parks reconstruction) and improvement of cities, implementation of constant ecological and sanitary control over the activity of industrial enterprises.
To implement the priority tasks, it is necessary to ensure the unity of the subject interaction in the process of strategic maintenance of the growth of the welfare level of the urban population. Taking into account the unity of the subject-object nature of this interaction, the necessity for improving the organizational infrastructure of the local self-government bodies of Kremenchuk (Official website of Kremenchuk town council; Official website of Kriukiv district council) has been substantiated in the part concerning creation of the Office of cooperation with subjects of the market of educational services and business structures, principles (social partnership principle, network principle of organization of the city system of continuous education, the principle of collective access to resources, the principle of selfdevelopment, the principle of transparency of financial activities); functions (coordination, uniting, controlling, informational, analytical, forecasting, regulatory, intersectoral, innovation, quality management) (Fig. 4).

Thus, on the basis of thestudy, the following conclusions can be drawn: firstly, the imperatives of increasing the welfare of an industrial city that are strategic in nature are identified and should be embedded in the system of strategic development of the socio-economic sphere of the state and the region, which will be the scientific basis for the future research; secondly, in order to increase the welfare of the urban population, orientation towards long-term and mutually beneficial relations with the actors involved in the process should be ensured, which recognize the common tasks and are ready to work together to implement strategic imperatives. In order to ensure the unity of the subjects, improvement of the organizational structure of the local self-government bodies of Kremenchuk in the part of the creation of the Office of cooperation with the subjects of the market of educational services and business units, the principles and functions are defined.

\section{Conclusions}

As a result of the research, it is proved that since the problem of the low welfare of the local population is complex, ensuring the increase of the level and quality of life should be based on a scenario analysis using the synthesis of theoretical and empirical methods.

The factors influencing the material welfare of the population are identified, a system of criteria (economic, social, environmental, institutional) is proposed, the use of which allows consistently determining the dominant external influences on the living standards of the population and identifying the most powerful of them; An algorithm for forecasting the living standards of the local population is developed.

As a result of computer processing of the relationship of factors and on the basis of the analysis of the corresponding dependencies, the direct dependence function is selected, which was used to determine 
that the number of small businesses per 10,000 of the present population grows by one unit, the average wage in the city Kremenchuk increase is $1.13 \mathrm{UAH}$; by increasing the subsistence minimum of $1 \mathrm{UAH}$, the average salary will increase by $1.55 \mathrm{UAH}$; while increasing productivity for $1 \mathrm{UAH}$, the average salary increase is almost $0.43 \mathrm{UAH}$; by increase in nominal wages is UAH 1 , the average salary will increase by UAH 0.91; by increasing the minimum wage of $1 \mathrm{UAH}$, the average wage reduced by $1.28 \mathrm{UAH}$. On the basis of this, with the use of the programs Statistica 6.0 and Microsoft Excel received predictive values of the material welfare of the local population. The adequacy of the models and forecasts received is verified by means of verification of the predicted values by the inverse method (with a comparison of statistical and verification values).

In the conditions of growing requirements for the continuous modernization of the economy, there is a need for the formation of new paradigmatic principles for increasing the welfare of the urban population, owing to the fragmentation of existing approaches to the latter phenomenon. It is substantiated that the imperatives of raising the level of welfare of the urban population should have a strategic character and be embedded in the system of strategic development of the social sphere of the state and the region through the implementation of the following directions: elimination of social imbalances; raising standards of living; creation of a comfortable environment for the population; creation of more favourable conditions for business development and improvement of the city's business climate; development and modernization of hightech production; creation of favourable conditions for entering the city of domestic and foreign investments; development of municipal infrastructure; providing the city's population with affordable, high-quality, and comfortable accommodation; ensuring the filling of budgets of all levels, etc. Based on the foregoing, the concept of strategic provision of urban welfare growth will be formed in subsequent scientific studies.

\section{References:}

Belyaeva, L. A. (2009). Uroven i kachestvo zhizni. Problemy izmereniya i interpretatsii [Level and Quality of life. Problems of measuring and interpretation]. Sociological research, no. 1, pp. 33-42.

Druzhynina, V. V., Alekseeva, N. F., Zalunina, O. M. (2017). Formuvannia bahatorivnevoi systemi pokaznykiv vymiru dobrobutu naselennia [Formation of a multi-level system of indicators of welfare measurement people]. Actual problems of the economy, vol. 190, no. 4, pp. 100-112.

Druzhynina, V. V., Chornous, O. I. (2011). Optymizatsiia fondu zarobitnoi platy na pidpryiemstvakh v umovakh ekonomichnoi kryzy [Optimization of the wage fund at enterprises in the conditions of the economic crisis]. Actual problems of the economy, vol.123, no. 9, pp. 112-117.

Druzhynina, V. V. (2014). Mistsevyi rynok pratsi: umovy funktsionuvannia, metody ta sposoby zabezpechennia zbalansovanosti [Local labor market: conditions of functioning, methods and methods of ensuring balance]. Donetsk: South-East. (in Ukrainian)

Green, K. B. (1987). Cognitive Models of International Decisionmaking and International Stability. Systems Research, vol. 4, no. 4, pp. 251-267.

Ihnatiuk, A. O. (2010). Metodychni pidkhody do vymiriuvannia rozvytku suspilnoho dobrobutu [Methodological approaches to measuring the development of social welfare]. Economic Space: Collection of scientific works, vol. 34, pp. 53-65.

Kholodok, Y. I., Lysenko, S. M. (2011). Otsinka rivnia zhyttia naselennia v Ukraini [Estimation of living standards in Ukraine]. Proceedings of the Actual problems of economic and social development of the region: a collection of materials of the All-Ukrainian scientific and practical conference (Ukrainian, Krasnoarmeysk, December 16, 2011). Krasnoarmeysk: KII DonNTU, pp. 162-165.

Libanova, E. M. (ed.) (2007). Liudskyi rozvytok rehioniv Ukrainy: analiz ta prohnoz [Human Development of the Regions of Ukraine: Analysis and Forecast], Kyiv: Institute of Demography and Social Studies of the National Academy of Sciences of Ukraine. (in Ukrainian)

Libanova, E. M., Hladun, O. M., Lisohor, L. S. (2013). Vymiriuvannia yakosti zhyttia v Ukraini: analitychna dopovid [Measurement of quality of life in Ukraine: analytical report]. Kyiv: Institute of Demography and Sociology. (in Ukrainian)

Likhonosova, H. S. (2012). Sotsialne vidtorhnennia : napriamy proiavu v Ukraini [Social exclusion: directions of display in Ukraine]. Time description of economic reform, no. 3(7), pp. 124-130. (in Ukrainian)

Lukyanchenko, O., Sevka, V.G. (2012). Formuvannia systemy monitorynhu yakosti zhyttia naselennia mist [Formation of a system for monitoring the quality of life of urban populations]. Economy of construction and municipal economy, vol. 8, no. 3, pp. 219-226.

Makarova, O. V., Hladun, O. M. (2012). Rehionalnyi indeks liudskoho rozvytku: prychyny ta napriamy vdoskonalennia metodyky rozrakhunku [Regional index of human development: reasons and directions of perfection of the calculation method]. Ukrainian statistics, no. 1, pp. 10-15.

Mandybura, V. O. (1998). Riven zhyttia naselennia Ukrainy ta problemy reformuvannia mekhanizmiv yoho rehuliuvannia [The level of life of the population of Ukraine and the problem of reforming the mechanisms for its regulation]. Kyiv: Parliamentary View. (in Ukrainian) 
Official website of Kremenchuk town council. Available at: http://www.kremen.gov.ua/(accessed 28 December 2017).

Official website of Kriukiv district council. Retrieved from: http:www.kriukiv-rada.gov.ua/ (accessed 28 December 2017).

Omelchenko, O. I. (2010). Metodolohichni zasady otsiniuvannia rivnia zhyttia naselennia v rehionakh Ukrainy [Methodological bases of estimation of living standards of the population in the regions of Ukraine]. Problems of the economy, no. 2, pp. 81-90.

Pigou Arthur C. (1932). The Economics of Welfare. Fourth edition. London: Macmillan and Co., 386.

Pidhornyi, A. Z., Vitkovska, K. V. (2012). Statystychne otsiniuvannia ta modeliuvannia demohrafichnykh protsesiv na rehionalnomu rivni [Statistical evaluation and modeling of demographic processes at the regional level]. Metodolohiia statystychnoho zabezpechennia rozvytku rehionu [Methodology of statistical support for the development of the region]. Odessa: Atlant, pp. 6-42.

Popova, T. L. (2011). Riven ta yakist zhyttia naselennia Ukrainy yak pokaznyk diievosti sotsialnoi derzhavnoi polityky [The level and quality of life of the population of Ukraine as an indicator of the effectiveness of social state policy]. Derzhavne upravlinnia: teoriia ta praktyka [Public administration: theory and practice]. (electronic journal), no.1, pp. 1-6. Retrieved from: http://www.academy.gov.ua/ej/ej13/txts/Popova.pdf (accessed 9 December 2017).

Pryimak, V. I. (2011). Nechitke otsiniuvannia rivnia ekonomichnoho dobrobutu domohospodarstv [Fuzzy estimation of the level of economic welfare of households]. Economy: realities of time, vol. 1, no. 1, pp. 149-158.

Sen, A. (1977). The Standard of Living. The Perception of Welfare Inequality. European Economic Review, 2, vol. 10, pp. 189-207.

Smith, A. G. (1997). Human rights and choice in poverty: Food insecurity, dependency, and human rights-based development air for the Third World rural poor. London: Praeger, 182.

The Main Statistical Office in Poltava region (2008-2015). Available at: pl.ukrstat.gov.ua. (accessed 27 November 2017).

Verbytska, H. L. (2010). Problemy bidnosti ta rivnia zhyttia naselennia Ukrainy [Problems of poverty and living standards in Ukraine]. Ukrainian national idea: reality and prospects, vol. 20, no. 2, pp. 305-309.

Zherebin, V. M., Romanov, A. N. (2015). Uroven zhyzny naselenyia : osnovnie katehoryy, kharakterystyky y metodi otsenky [Standard of living of the population: the major categories, properties and methods of assessment]. Moscow: INFRA-M. (in Russian)

Zvigun, I. A. Ekonomichni peredumovy dobrobutu naselennia Ukrainy [Economic preconditions of welfare of the population of Ukraine]. Retrieved from: http://www.khntusg.com.ua/files/sbornik/vestnik_99/54.pdf. (accessed 29 December 2017) 